\title{
ATEBE
}

Dinî Araștırmalar Dergisi Journal for Religious Studies e-ISSN: 2757-5616

ATEBE Dergisi / Journal of ATEBE

Sayı: 6 (Aralık / December 2021), 39-52.

\section{İngiliz İdaresi Döneminde Kıbrıs'ta İki Kilise Krizi}

\author{
The Two Church Crises in Cyprus During the British Rule
}

\author{
Mustafa Şengil \\ Dr. Diyanet İşleri Başkanlığ \\ Ph.D. Presidency of Religious Affairs \\ Konya, Turkey \\ mustafasengil_85@hotmail.com \\ orcid.org/ 0000-0002-2904-1776 \\ https://ror.org/007x4cq57
}

\section{Makale Bilgisi / Article Information}

Makale Türü / Article Types: Araștırma Makalesi / Research Article Geliş Tarihi / Date Received: 11 Haziran/June 2021

Kabul Tarihi / Date Accepted: 22 Kasım/November 2021

Yayın Tarihi / Date Published: 31 Aralı/December 2021

Yayın Sezonu / Pub Date Season: Aralı/December

Atıf / Cite as: Şengil, Mustafa. “İngiliz İdaresi Döneminde Kıbrıs'ta İki Kilise Krizi”. ATEBE 6 (Aralık 2021), 39-52. https://doi.org/10.51575/atebe.951301

İntihal / Plagiarism: Bu makale, iTenticate yazılımınca taranmıştır. İntihal tespit edilmemiştir/This article has been scanned by iTenticate. No plagiarism detected.

Etik Beyan/Ethical Statement: Bu çalışmanın hazırlanma sürecinde bilimsel ve etik ilkelere uyulduğu ve yararlanılan tüm çalışmaların kaynakçada belirtildiği beyan olunur/It is declared that scientific and ethical principles have been followed while carrying out and writing this study and that all the sources used have been properly cited (Mustafa Şengil).

Yayıncı / Published by: Ankara Sosyal Bilimler Üniversitesi / Social Sciences University of Ankara. Bu makale Creative Commons Alıntı-GayriTicariTüretilemez 4.0 (CC BY-NC 4.0) Uluslararası Lisansı altında lisanslanmıştır. This article is an open access article distributed under the terms and conditions of the Creative Commons Attribution-NonCommercial-NoDerivatives 4.0 (CC BY-NC 4.0) International License. 


\title{
İngiliz İdaresi Döneminde Kıbrıs'ta İki Kilise Krizi*
}

Öz

Bu çalışma Osmanlı Devleti'nin Kıbrıs Adası'nı fethi ile özgürlüğünü yeniden kazanmış olan Kıbrıs Rum Ortodoks Kilisesi'nin, İngiliz idaresi döneminde yaşamış olduğu iki siyasi kilise krizini konu etmektedir. İngilizlerin Kıbrıs'ta idaresi iki döneme ayrılmaktadır. Birincisi 1878 yılında Osmanlı Devleti ile yapılan iki maddelik antlaşma kapsamında 1914 yılına kadar devam eden ve adanın fiilen Osmanlı toprağı olarak kabul edildiği dönem; ikincisi ise 1914 yılında İngiltere'nin adayı tek taraflı ilhakından 1960 yılında Kıbrıs Cumhuriyeti'nin kurulmasına kadar olan dönemdir. İngiliz idaresi döneminde gerçekleșmiş olan kilise krizlerinin ilki 1900-1910 yılları arasında Kitium Piskoposu Kyrillos Papadopoulos ile Girne Piskoposu Kyrillos Basileiou arasında gerçekleşmiştir. İkincisi ise 1933-1947 yılları arasında Baf Metropoliti Leontios Leontiou'nun 1931 isyanları sebebiyle ada dışında sürgünde olan metropolitlerin adaya dönmeden seçim yapılamayacağını beyan etmesi sebebiyle gerçekleşmiştir. Kıbrıs Rum Ortodoks Kilisesi otosefal bir kilise olması sebebiyle iç işlerine diğer kiliseleri karıştırmak istememiş, ancak çıkmaza giren piskoposluk seçimi nedeniyle müdahale kaçınılmaz olmuştur. Bugüne kadar siyasetteki etkisi var olagelen Kıbrıs Rum Ortodoks Kilisesi, 20. Yüzyılın henüz başında geçirmiş olduğu kilise krizlerini ancak siyasetin etkisi ve yardımıyla așabilmiștir. Kıbrıs'ta ilk Yunan bayrağı birinci kilise krizi döneminde bir taraftar toplama çalışması olarak II. Kyrillos (Kyrillos Papadopoulos) tarafından Trooditissa Manastırı'na çekilmiştir. Ancak Kıbrıs Adası'nın ne daha önceki dönemlerde ne de şimdi Yunanistan ile hiçbir bağı yoktur. Kıbrıs Adası'nda yaşayan Rumlar ile Yunanistan arasında bir bağ olușturmaya çalıșan ve bunu iddia eden de yine kilisedir. Kıbrıs Cumhuriyeti birinci Cumhurbaşkanı III. Makarios'un başpiskopos seçilmesine giden süreçte bahsedilen iki kilise krizi büyük önem taşımaktadır. Bu dönemde bașpiskopos adayları arasında, rakip adaya karşı Enosis'i ateșli bir șekilde savunmamak, İngiliz idaresine fazla yakın olmak gibi suçlamalar olmuştur. III. Makarios hem ateșli bir şekilde Enosis'i savunmuş, hem de İngiliz idaresi ile her zaman çatışma halinde olmuştur. Bu süreç ona önce bașpiskoposluk, sonrasında ise Kıbrıs Cumhuriyeti Cumhurbaşkanlığı getirmiştir. Kıbrıs'ta zikri geçen dönemde özellikle ön plana çıkan Türk düşmanlığı, başpiskopos olmanın ilk şartı sayılmıştır. Şöyleki; İngilizler adayı tek taraflı ilhak ettikten sonra İngilizlerin adayı kendilerine bırakacağına neredeyse emin olan Rum Ortodoks Kilisesi başpiskoposları, önce İngiliz idaresi düşmanlığı, sonra Türk düşmanlığı üzerinden kilise propagandası yapmışlardır. Çalışmada otosefal bir kilise olan Kıbrıs Rum Ortodoks Kilisesi'nin, kilise içi anlașmazlıklardaki tavrı ile kilise kurallarına bağlılığı da ele alınmaktadır. Enosis düşüncesinin piskoposluk seçimine etkisinin daha net görüleceği bu iki kriz, kilisenin bugününü anlamak açısından oldukça önemlidir.

Anahtar Kelimeler: Dinler Tarihi, Kıbrıs, Kilise, Ortodoks, Başpiskopos, Rum.

\section{The Two Church Crises in Cyprus During the British Rule}

\begin{abstract}
This study is about two political church crises that the Greek Cypriot Orthodox Church, which regained its freedom with the conquest of the island of Cyprus by the Ottoman Empire, experienced during the British rule. The British administration in Cyprus is divided into two periods. The first is the period that lasted until 1914 within the scope of the two-point agreement with the Ottoman Empire in 1878, and when the island was actually accepted as Ottoman territory; the second is the period from the British unilateral annexation of the island in 1914 to the establishment of the Republic of Cyprus in 1960. The first of the church crises during the British administration took place in 1900-1910, between the Bishop of Kitium Kyrillos Papadopoulos and the Bishop of Kyrenia Kyrillos Basileiou. The second one took place in 1933-1947, because of the Metropolitan of Paphos Leontios Leontiou's declaration that the metropolitans who were in exile outside of the island due to the 1931 revolts declared that elections
\end{abstract}

* Bu çalışma 2020 yılında tamamladığımız “Osmanlı’dan Günümüze Kıbrıs İnanç Tarihi” adlı doktora tezi esas alınarak hazırlanmıștır./ This article is extracted from my doctorate dissertation entitled "Religious History of Cyprus from Ottomans to Nowadays" year 2020. 
could not be held without their return to the island. Since the Greek Cypriot Orthodox Church is an autocephalous church, it did not want to interfere with other churches in its internal affairs, but the intervention was inevitable due to the stalemate choice of diocese. The Greek Cypriot Orthodox Church, which has had an influence in politics until today, was able to overcome the church crises it had experienced at the beginning of the 20th century only with the influence and help of politics. The first Greek flag in Cyprus was used as a supporter gathering effort during the first church crisis. He was taken to Trooditissa Monastery by Kyrillos (Kyrillos Papadopoulos). However, the island of Cyprus has no ties with Greece, neither in previous periods nor now. It is the church that tries and claims to create a bond between the Greeks living on the island of Cyprus and Greece. The church crises mentioned in the process played an important role in the election of Makarios III, the first president of the Republic of Cyprus, as archbishop. During this period, among the archbishop candidates, there had been accusations of not defending Enosis passionately against the rival island and being too close to the British administration. Makarios III fiercely defended Enosis and was, at the same time, always in conflict with the British administration. This process brought him first the archbishopric, and then the Presidency of the Republic of Cyprus. The Turkish hostility, which came to the fore in the aforementioned period in Cyprus, was considered the first condition of being an archbishop. After the British annexed the island unilaterally, the archbishops of the Greek Orthodox Church, who were almost sure that the British would leave the island to them, made church propaganda out of hostility to the British administration and then to the Turks. In the study, the attitude of the Greek Cypriot Orthodox Church, which is an autocephalous church, in intra-church disputes and its adherence to church rules are also discussed. These two crises, in which the effect of the idea of enosis on the choice of diocese will be seen more clearly, are very important in terms of understanding the present day of the church.

Keywords: History of Religions, Cyprus, Church, Orthodox, Archbishop, Greek.

\section{Giriş}

İngiliz idaresi döneminde Kıbrıs'ta iki kilise krizi adını verdiğimiz bu makale Osmanlı Devleti hâkimiyeti sonrası Kıbrıs Rum Ortodoks Kilisesi'nin Enosis düşüncesine katkıları ile Enosis düşüncesinden kaynaklanan otorite problemleri ile sürgünler sebebiyle adada zamanında yapılamayan iki başpiskopos seçimini konu edinmektedir. Makalede, 1821 Yunan İsyanından itibaren Rumlar üzerinde etkili olan Helenizm düşüncesi ve Rum Milliyetçiliği sebebiyle ortaya çıkan kilise krizleri ve bu krizlerin aşılmasında kilise dışı müdahalelerin etkisi olup olmadığı ortaya koyulmuştur. Sir George Francis Hill tarafından yazılan, Nazım Can Serbest tarafından Türkçeye çevrilen Kıbrıs Tarihi Osmanlı ve Íngiliz Ídaresi Dönemi (1571-1948) adlı eserde bu krizlere kısmen değinilmiştir. Müracaat ettiğimiz diğer kaynaklarda ise derli toplu olmamakla birlikte bu krizlerden bahsedilmiştir. Makale bu dağınık bilgileri kronolojik olarak bir araya getirmeyi de hedeflemektedir. Makale kilisenin milliyetçilik üzerindeki etkisini de Enosis bağlamında ortaya koymuştur.

\section{1. İngiliz İdaresi Döneminde Kilisenin Durumu}

Kıbrıs'ta Ortodoks Hıristiyan olan Rumlar İngilizlerin ada yönetimini devralmaları ile birlikte farklı Hıristiyan mezhebine mensup dindaşları tarafından idare edilmeye başlamıştır. Bu dönemde Ortodoks Rumlar İngilizlerden dini ayrıcalık beklemiş, aynı dine mensup olmaları nedeniyle Kilisenin söz sahibi olacağı inancını taşımıştır. ${ }^{1}$ Ancak

1 Münir Yıldırım, Kıbrıs Rum Ortodoks Kilisesi: İlk Dönem Bir Hristiyan Kilisesi Olarak (Ankara: Aziz Andaç, 2008), 67. 
Ortodoks Kilisesi'nin bu beklentisi İngiliz yönetimi tarafından karşılık görmemiş aksine adada isyanlara sebep olmuştur. ${ }^{2}$

Kıbrıs Adası'nın İngilizlere devredilmesi adadaki Ortodoks Kilisesi tarafından ilk etapta olumlu karşılanmıştır. Bu dönemde Kıbrıs Rum Ortodoks Kilisesi Başpiskoposu olan Sofroniyos, İngiliz idaresinin kendilerine özgürlüklerini artırmada yardımcı olacağına inancının tam olduğunu belirtmiştir. Kitium Piskoposu ise Kıbrıs'ın Yunanistan'a ilhak edilmesinde İngiltere'nin yardım etmesi koşuluyla yeni idareyi kabul edeceklerini bildirmiştir. ${ }^{3}$ Tüm Osmanlı topraklarında hızla yayılan milliyetçilik akımlarından etkilenen Kıbrıs Ortodoksları da İngilizlerden her defasında Yunanistan'a bağlanmayı talep etmişlerdir. Özellikle kilise bu uğurda yapılmış olan hiçbir faaliyetten geri durmamıştır.

Kıbrıs'ta Osmanlı Devleti'nin adayı idare ettiği dönemde Rum halkına verilen haklar, İngiliz idaresi döneminde kısıtlanmıştır. Kilisenin bağış toplamasına ve kilise adına din vergisi almasına Osmanlı döneminde izin verilmiş, hatta aynı zamanda kilisenin vergileri toplayabilmesi için idare tarafından askeri destek de sağlanmıştır. İngiliz idaresi döneminde ise, yönetim bu uygulamanın doğru olmadığını, eşitlik ilkesine aykırı olduğunu beyan ederek ilgili uygulamaya son vermiş, askeri destek de vermeyeceğini belirtmiştir. Bu durum kiliseyi ekonomik olarak zor duruma düşürmüştür. ${ }^{4}$

1907 yılında İngiltere, Kıbrıs'ın ekonomik ve idarî yapılanmasını incelemek üzere Sömürgeler Bakanlığında müsteşar olan Winston Churchill'i adaya göndermiştir. Churchill'in Kıbrıs'a gelmesini bir firsat olarak değerlendiren Rumlar, adanın Yunanistan'a bağlanmasını istedikleri bir bildiri yayınlamışlardır. Dönemin şartlarını ve Enosis düşüncesinin temelsizliğini göstermesi bakımından Churchill'in bu bildiriye verdiği cevap önem arz etmektedir. ${ }^{5}$

“... Fakat bu cemaatin (adanın) Yunanistan'ın bir parçası olduğu neye dayanır? Ada ile Yunanistan arasında ne tarihî ne de coğrafî bir bağ vardır. Adanın tarihî devirlerde Mısır, Iran, Asur, Roma, Venedik, Ceneviz ve Osmanlı Devletleri'ne bağlı olduğunu görüyoruz. Hiçbir zaman Yunanistan'a bağlı olduğunu tarih kaydetmiyor. Kıbrıs en geniş bir hayal ile bile coğrafî bakımdan Yunanistan'ın bir parçasını teşkil edemez. Kıbrıs'ta şimdi yaşayan insanlar Yunanlı değildir. Bunlar buraya göç eden Mısırlılar ile

2 Detaylı bilgi için bk. Turgay Bülent Göktürk, "Rumlar'ın Kıbrıs'taki Enosis İsteklerinin Şiddete Dönüşmesi: 1931 İsyanı”, Çağdaş Türkiye Tarihi Araştırmaları Dergisi 7/16-17 (2008), 335-363.

3 Halil Fikret Alasya, Kıbrıs ve Rum-Yunan Emelleri (Lefkoşa: KKTC Milli Eğitim ve Kültür Bakanlığı, 1992), 24; Ahmet C. Gazioğlu, Ingiliz Yönetiminde Klbris II, 1878-1952: Enosis Cemberinde Türkler (İstanbul: Kıbrıs Araştırma ve Yayın Merkezi (CYREP), 1996), 29-31; Yıldırım, Kıbrıs Rum Ortodoks Kilisesi, 70.

4 Şükrü S Gürel, Kıbrıs Tarihi (1878-1960): Kolonyalizm, Ulusçuluk ve Uluslararası Politika (Ankara: Kaynak Yayınları, 1984), 44-45; Ergenekon Savrun, "1571 Türk Yönetiminden, 1878-1925 İngiliz Taç Kolonisi’ ne; Kıbrıs Üzerinde Enosis Faaliyetleri ve İngiliz Stratejisi”, Uluslararası Beşeri Bilimler ve Ĕgitim Dergisi 3/1 (01 Nisan 2017), 11.

5 Bekir Bozkurt, Ingiltere'nin Kıbrıs Adasını İlhak Süreci (Ankara: Ankara Üniversitesi, Sosyal Bilimler Enstitüsü, Yüksek Lisans Tezi, 2005), 85. 
İngiliz İdaresi Döneminde Kıbrıs'ta İki Kilise Krizi

Yunanlıların karışmasından meydana gelen melez bir tiptir. Yalnız Yunan dili bunların Yunan geleneklerine bağlı kalmalarını sağlamıştır..."6

Osmanlı döneminde diğer hiçbir kilisenin sahip olmadığı ayrıcalıklara sahip olan Kıbrıs Rum Ortodoks Kilisesi hem padişah hem de İstanbul Patrikliği tarafından gözetilmekteydi.7 İngiliz idaresi döneminde Kıbrıs Rum Ortodoks Kilisesi'nin Osmanlı döneminde kazandığı birçok ayrıcalık yok sayılmıştır. İngilizler kendi atamış oldukları komiser ve görevliler dışında yerel halktan kişilerin veya kurumların İngiliz idaresi kadar yetkili olmasına müsaade etmemişlerdir. ${ }^{8}$ İngilizlerin bu yöntemi, Osmanlı Devleti'nin adaya hâkim olduğundan beri birçok konuda söz sahibi olan Ortodoks Kilisesi'ni ve onun müntesibi olan Rumları memnun etmemiş, bu hakları geri kazanmak için her yolu denemişlerdir. ${ }^{9}$

Ortodoks Kilisesi'nde ılımlı Enosis taraftarlığı yapanlar ile militan Enosisçiler arasında daha sonra "Kilise Krizi" diye anılacak olan kriz baş göstermiştir. Bu kriz Girne ve Kition piskoposlukları arasında yaşanmış ve kiliseye on yıl başpiskopos atanamamıștır. ${ }^{10}$ On yıl sonra militan ve genç Hıristiyanların desteklediği Kition Piskoposluğunun bu mücadeleden galip çıkması da adada Rum Ortodoks Kilisesi'nin ırkçı tarafının ağır basmaya başladığını göstermesi bakımından önemlidir. ${ }^{11}$

İngiliz idaresi, adada fiili olarak idareyi devralmasının ardından Ortodoks din adamlarına tanınmış olan imtiyazların tanınmadığını bildirmiştir. Başpiskopos Sofroniyos 14 Ağustos 1878 tarihinde Wolseley ile yapmış olduğu görüşmede, Osmanlı döneminde toplamış oldukları aidatları İngiliz yönetimi döneminde zaptiye olmadan toplayamadıklarını bildirmiştir. Wolseley ise aslında böyle bir uygulamanın olmadığını, sadece ilk yıla mahsus yardımcı olacağını ancak bundan sonra böyle bir şeye yardımcı olmayıp müsaade de etmeyeceğini Sofroniyos'a bildirmiştir. ${ }^{12}$ Lefkoşa Piskoposu ise Osmanlı yönetiminin kendilerini vergiden muaf tutmalarına rağmen mevcut yönetimin, mülklerin tam bedelini çıkararak vergilendirildikleri şikâyetinde bulunmaktadır. ${ }^{13}$ Yüksek Komiser Wolseley göreve geldiğinde ada içinde yapmış olduğu gezilerde manastırları ve kiliseleri de gezmiş, bu mabetlerde tarihi eser niteliği taşıyan çok fazla eser görmüștür. Ayrıca kiliselere ait birçok arazinin de olduğuna inandığını günlügüne yazmıștır: "Rahiplerin ve keşişlerin dilenci olanları şu ana kadar herhangi bir kanuna dayanmadan vergiden muaflı̆ın tadını çıkardılar. Ancak ben onların da herkes gibi vergi ödemesi konusunda mücadele edeceğim. ${ }^{114}$ Bu davranışı ile Wolseley İngiliz idaresi altında

6 Halil Fikret Alasya vd., "İngiliz İdaresinde Tatbik Edilen Politika”, Kıbrls ve Türkler (Ankara: Türk Kültürünü Araştırma Enstitüsü, 1964), 73-74.

7 Benedict Englezakis, Studies on the History of the Church of Cyprus, 4th-20th Centuries (Great Britain: Variorum, 1995), 427-434.

8 Gürel, Kıbrıs Tarihi (1878-1960), 44; Gazioğlu, Ingiliz Yönetiminde Kıbrıs II, 1878-1952, 35.

9 Yildırım, Kıbris Rum Ortodoks Kilisesi, 74.

10 Yildırım, Kıbris Rum Ortodoks Kilisesi, 76.

11 Niyazi Kızılyürek, Milliyetçilik Kıskacında Kıbrıs (İstanbul: İletişim Yayınları, 2002), 80-81.

12 Anne Cavendish (ed.), Cyprus 1878: The Journal of Sir Garnet Wolseley (Nicosia: Cultural Centre of the Cyprus Popular Bank, 1991), 46-47.

13 W. H. (William Hurrell) Mallock, In an Enchanted Island or A Winter's Retreat in Cyprus (London: R. Bentley \& Son, 1892), 209.

14 Cavendish, Cyprus 1878, 141-146.

https://dergipark.org.tr/tr/pub/atebe 
hiç kimseye haksızlık yapılmadığını göstermek istemiştir. ${ }^{15}$ Ayrıca bu dönemde kilise gelirleri tüm ada gelirlerinin üçte birini oluşturmaktadır. ${ }^{16}$ Bir İngiliz yöneticisinin eşi görüştükleri bir papazın kendilerine, manastıra gelen misafirleri yedirme ve barındırma mecburiyetleri olduğundan, Osmanlı Devleti tarafından kendilerine vergi muafiyeti sağlandığını ancak İngilizler adaya hâkim olduktan sonra uygulanan vergi usulünden şikâyetçi olduklarını, manastırların maddi ihtiyaçlarını karşılayabilmek için misafirlerin vereceği yardımları beklediklerini belirtmiştir. ${ }^{17}$ Kıbrıs'ta Osmanlı idaresi döneminden itibaren tüm din mensuplarına kendi din adamlarını halk tarafından seçme hakkı tanınmıştır. Seçilen din adamlarına ise halklarına zulüm ve isyan etmedikleri müddetçe karışılmamıştır. İngiltere'de ise dini kurumların başındaki görevliler başbakan tarafından atanmakta ve siyasetin kiliseye müdahalesi kaçınılmaz olmaktaydı. Bu durum Kıbrıs Adası'nda özgürlüklere alışmış olan Hıristiyan din adamlarına garip gelmiştir. ${ }^{18}$

Osmanlı Devleti'nin bir uygulaması olan millet sistemi neticesinde başpiskopos ve piskoposların yargılama yapma yetkisi de İngiliz idaresi ile büyük oranda yürürlükten kaldırılmıştır. Ancak her iki tarafın veya bir tarafın Ortodoks Rum olduğu durumlarda boşama için kiliseye müracaat edilmesine müsaade edilmiştir. ${ }^{19}$

İngiliz idaresi döneminde herhangi bir yaptırım olmadığından ve kilise görevlilerinin yanına zaptiye verilmediğinden Rum halkı kiliselere yapılan ödemeleri kesmiştir. Bu dönemde Rumlar, Hıristiyan din adamlarının kilise malları ve toplanan paralarla okul, kilise bakımı ve ihtiyaç sahiplerine yardım yapmaları gerekirken kendilerinin zenginleștiğini düşünmekteydi. Yapılan ödemelerin kesilmesi üzerine bazı din adamları da misilleme olarak kiliseleri ibadete kapatmıştır. ${ }^{20}$

İngiliz yönetimi kiliselerin zorla para ve aidat toplamasını iptal etmiş, kilise ve manastırlara bağışlanan arazilerin ve mülklerin kira gelirleri, papazlığa atama için alınan ücretler, kiliselerin kutsanması sebebiyle alınan ücretler, evlendirme belgesi ve boşamalardan alınan ücretler ile gönüllü yapılan yardımlar bu dönemde kilise gelirlerini oluşturmuştur. ${ }^{21} \mathrm{Bu}$ dönemde halktan toplanan kilise vergileri kilise görevlileri tarafından toplanmış, halkın vergi vermedeki isteksizliği sebebiyle gelirlerde büyük oranda düşüş olmuştur. Bu sebeple başpiskopos ve Yürütme Meclisi Rum üyeleri vergilerin yönetim tarafından toplanmasını talep etmiş ancak Kavanin Meclisi'nin İngiliz üyeleri bu konuda bir sonuca varamamıştır. ${ }^{22}$

Eski güçlerini ve gelirlerini kaybeden Hıristiyan din adamları; Başpiskopos Sofroniyos, Baf, Larnaka, Girne Piskoposları bu durumu düzeltmek ve yeni yönetime izah

15 Cemil Çelik, İngiliz Yönetiminde Kıbrıs'ın İdari ve Sosyal Durumu (1878-1914) (Antalya: Akdeniz Üniversitesi, Sosyal Bilimler Enstitüsü, Doktora Tezi, 2012), 223.

16 Sir George Francis Hill, A History of Cyprus (Cambridge: Cambridge University Press, 1952), 4/444-445.

17 Esmé Scott-Stevenson, Our Home in Cyprus (Chapman and Hall, 1880), 133-134.

18 Mustafa Şengil, Mavi Vatanın Kudüsü (Kıbris'ta Din ve Siyaset) (İstanbul: Hikmetevi Yayınları, 2021), 121.

19 Henry Thomas Forbes Duckworth, The Church of Cyprus (London: Society for Promoting Christian Knowledge, 1900), 76-77.

20 Duckworth, The Church of Cyprus, 77.

21 Duckworth, The Church of Cyprus, 77.

22 National Archive NA, Colonial Office [CO], 69/14. 
edebilmek için 16 Şubat 1879 tarihinde Rum Ortodoks Kilisesi'nin tarihini anlatan bir bildiri hazırlamıștır. Bu bildiride Osmanlı idaresi döneminde din adamlarının, toplumun ve mensubu oldukları dinin lideri olarak telakki edildiklerini, bu durumun ayrıcalıklarla beraber sorumluluk da taşıdığını, İngiliz idaresi ile kiliselerin resmi fonksiyonlarının ve etkinliklerinin azaldığını belirtmişlerdir. ${ }^{23} \mathrm{Bu}$ girişimlerden sonuç alınamayınca Kıbrıs Başpiskoposu Sofroniyos Osmanlı yönetimine, İngiliz yönetiminin kilisenin imtiyazlarını tanımadığı ile ilgili bir arzuhal göndermiştir. ${ }^{24}$

Ortodoks din adamları İngiliz yönetimine karşı tepki gösterirken İngiliz yönetimi de kilisenin yargılama yetkisinin kısıtlanması yoluyla kilisenin ada Rumları üzerindeki etkisini azaltmış, kiliseler tarafından toplanan zorunlu aidatları kaldırmak suretiyle de kilisenin ekonomik gücünü zayıflatmıştır. ${ }^{25}$

1900-1910 yılları ile 1933-1947 yılları arasında Kıbrıs Rum Ortodoks Kilisesi Başpiskoposluğu makamı, "kilise krizi" sebebiyle başpiskopos atanamadığından boş kalmış, kendi kendini yöneten apostolik bir kilise olan Kıbrıs Rum Ortodoks Kilisesi'nin işlerine çözüm için ada dışındaki kiliselerin müdahale etmesi adada yaşayan Hıristiyan Rum halkı oldukça rahatsız etmiştir. ${ }^{26}$ Kavanin Meclisi'nin Rum üyeleri, bu dönemde kilise mallarının sahipsiz kalması sebebiyle heba edildiğini ifade etmiştir. ${ }^{27}$

\subsection{Kilise Krizi 1900-1910}

Kıbrıs Rum Ortodoks Kilisesi, kilise meclisi tarafından yönetilmektedir. Kutsal Sinod $^{28}$ adadaki dört piskopos, Kikko ve Makhaira Manastırlarının başrahipleri ve iki ruhani kâtipten oluşmaktadır. Kutsal Sinod Meclisi Kıbrıs Başpiskoposu tarafından yönetilmektedir. Piskopos seçimi, başpiskoposun tüm kilise mensuplarına köylerde toplanıp temsilci seçmeleri için genelge yayınlaması ve seçilen temsilcilerin bașpiskoposluğa davet edilmesi sonucu kilise meclisi ile beraber yapılmaktaydı. Başpiskopos seçimi ise başpiskoposun ölümünden sonra kilise meclisinin toplanarak en kıdemli piskoposu vekil tayin etmesi ve başpiskopos seçimi için çalışmalara başlaması şeklinde yapılmaktaydı. Vekil seçilemezse Sinod Meclisi kilise mensuplarının toplanması için genelge yayınlamaktaydı.

Kıbrıs Rum Ortodoks Kilisesi içinde cereyan eden Kilise krizi 5 Şubat 1899 tarihinde Baf Piskoposu Epiphanius'un ölümünün ardından yerine biri tayin edilmeden Başpiskopos Sofroniyos'un hastalanması ile başlamıştır. Kilise hiyerarşisi içerisinde Baf Piskoposunun başpiskoposu belirleyecek olan seçimleri organize etme sorumluluğu vardı. Bu dönemde Kutsal Sinod şu isimlerden müteșekkildi: Başkan Kyrillos Papadopoulos Kitium Piskoposu, Kyrillos Basileiou Girne Piskoposu, Gerasimos Kikko Başrahibi, Ignatios Machaera Başrahibi, Philotheos Başpiskoposluk Kâtibi

23 Robert F. Holland - Diana Weston Markides, Britain and the Hellenes: Struggles for Mastery in the Eastern Mediterranean 1850-1960 (Oxford: Oxford University Press, 2006), 167.

24 Osmanlı Arşivi BOA, Hariciye Nezâreti Hariciye Tercüme Odası [HR.TO], No. 530, Gömlek No. 10.

25 İngiliz idaresi döneminde Kıbrıs Rum Ortodoks Kilisesi'nin kilise mülkleri ve vergilerle ilgili sorunları için bk. Celik, Ingiliz Yönetiminde Kıbrıs'ın İdari ve Sosyal Durumu, 198-233.

26 The Cyprus Gazette (20 Mart 1908), 6405-6407 No. 911.

27 The Cyprus Gazette (22 Şubat 1907), 6103-6106 No. 880.

28 Y1ldırım, Klbris Rum Ortodoks Kilisesi, 90-91. 
(Archimandrite), ${ }^{29}$ Joseph Başpiskoposluk Kâtibi (Exarch). ${ }^{30}$ Sofroniyos'un hastalığ sırasında 16 Mayıs 1900 tarihinde toplanan Sinod Meclisi şu kararları almıştı:

- “Kilise Meclisi, askıdaki başpiskoposluk seçimi süresince başpiskoposluk makamının tüm hak ve yetkilerini kullanır, tüm görevlerini yerine getirir.

- Kilise Meclisi başpiskopos ve Baf piskoposu yokluğunda, Larnaka ve Girne piskoposları, Kikko ve Machaera başrahipleri ve iki dini kâtip (Archimandrite ve Exarch) makamlarından olușur.

- Her oturumda en kıdemli piskopos Kilise Meclisine başkanlık eder, eğer bu kişi de yoksa ikinci en kıdemli piskopos başkan olur.

- Kilise Meclisi başkan dâhil en az dört üye ile toplanabilir.

- Bütün kararlar oy çoğunluğu ile alınır. Oylar eșit olduğunda başkanın oyu belirleyicidir.

- Kilise Meclisi pazar ve resmi tatiller hariç her gün toplanır. Gündem olmadığı zaman oturum kapanir.

- Kilise Meclisi genel sekreterini üyeleri arasından seçer ve bu kişi kilise meclisinin mührünü taşır.

- Kilise Meclisi ya da başpiskoposlukla ilgili her belge genel sekretere gönderilir ve genel sekreter bu belgeyi oturumda kilise meclisine sunar. Her belge kilise meclisi huzurunda tarih ve belge numarası atılarak açılır ve deftere kaydedilir.

- Belge oturum dışında alındıysa genel sekreter kilise meclisi üyelerini oturuma çağırır.

- Kilise Meclisi başpiskoposluk makamının hükûmet üzerindeki tüm yetkilerini kendi temsilcisi aracılığıyla kullanır ve bunu hükûmete mektup yoluyla bildirir. Kilise Meclisi bașpiskoposluk makamının çeşitli kurumlar üzerindeki başkanlık yetkilerini atanan bir kişi aracılı̆̆ıla kullanır.

- Oy birliği ya da çokluğu ile alınan tüm kararlara başkan dâhil tüm üyeler imza atar. Tersi yönde oy kullananlar "Katılmıyorum" ibaresini yazıp imzalar.

- Alınan karar kilise meclisi dıșındaki ilgili taraflara bașkanın imzası ve genel sekreterin başpiskoposluk mührüyle bildirilir. Başpiskoposluktan bağımsız genel içerikli konularla ilgili kararlar ilgili taraflara başkan dâhil tüm üyelerin imzası ile bildirilir.

- Bu kuralların kapsamadığı durumlarda da Kilise Meclisi durumu inceleyip karar verme konusunda yetkilidir.

- Buradaki geçici kurallar Kilise Meclisi tarafından çıkarılmış ve yayınlanmıștır.

Başkan Kyrillos, Kitium Piskoposu, Kyrillos, Girne Piskoposu, Gerasimos, Kikko Başrahibi, Ignatios, Machaera Başrahibi, Philotheos, Başpiskoposluk Kâtibi(Archimandrite), Joseph Başpiskoposluk Kâtibi(Exarch)”’31

29 Manastırlarda bulunan keşişlerin liderleri demektir. Kürşat Demirci, “Ortodoksluk”, Türkiye Diyanet Vakfi İslâm Ansiklopedisi (Ankara: TDV Yayınları, 2007), 33/412.

30 Sir Ronald Storrs - Bryan Justin O'Brien, The Handbook of Cyprus (London: Christophers, 1930), 46.

31 National Archive NA, Colonial Office [CO], 67/125 No. 266, Ek No. 1A. 
Başpiskopos Sofroniyos Sinod Meclisi'nin ikinci defa toplandığı 22 Mayıs 1900 tarihinde ölmüştür. ${ }^{32} 21$ Nisan 1909 tarihinde II. Kyrillos Papadopoulos'un başpiskopos seçilmesine kadar da bu makam boş kalmıştır. ${ }^{33}$ İki piskoposun ve özellikle başpiskoposun ölümü adada Rumlar arasında sıkıntılı bir sürecin başlamasına neden olmuştur. ${ }^{34}$ Sinod Meclisi oy birliğiyle başpiskoposluk ve Baf piskoposluğu makamlarının seçimlerini erteleyerek bu görevleri Sinod Meclisinin üstlenmesini kararlaştırmıştır.

Bu dönemde Enosis propagandalarının da etkisiyle en güçlü iki başpiskopos adayı Girne Piskoposu ve Kitium Piskoposuydu. Sinod Meclisi başkanı Kitium Piskoposu Kyrillos, kural dışı hareket ettiğinin anlaşılması üzerine başkanlığı bırakmış ve yerine Girne Piskoposu başkan olmuştur. Seçimlerin yasallı̆̆ ve köylerden belirlenen temsilcilerin yasal olarak seçilip seçilmediği ile ilgili meseleler sebebiyle itirazlar olmuş, Kitium Piskoposu taraftarları adaya İstanbul Patrikliğinden temsilci davet edilip araștırılmasını teklif etmiştir. Ancak Girne Piskoposu taraftarları bu durumun Kıbrıs Rum Ortodoks Kilisesi'nin bağımsızlığına zarar vereceğini düşündüklerinden kabul etmemiștir. ${ }^{35}$ Girne Piskoposuna göre Kıbrıs Rum Ortodoks Kilisesi otosefal bir kilise olduğundan Patrik sadece seçilen başpiskoposu onaylamalı, iç işlere karışmamalıydı.

Başpiskoposluk mücadelesi bu şekilde devam ederken İngiliz yönetimi Rum Ortodoks Kilisesi'nin iç meselesi olduğundan duruma müdahale etmek istememiş ancak kendini yapılan şikâyet ve yazışmalar sebebiyle, güvenlik problemleri de olduğundan hep işin içinde bulmuştur. Yüksek Komiser, Kitium Piskoposunun Yunanistan Kilisesinden hakemlik yapmak üzere kilise görevlilerini çağırma talebini de adayı Yunanistan'a bağlama amacıyla yapılmış siyasi bir hamle olması sebebiyle sakıncalı görmüştür. İngiliz idaresi, adanın içişlerine karışılmasını engellemek amacıyla İstanbul Patrikliği ve Yunanistan Hükûmeti ile görüşmeler yapmış, Kıbrıs Kilisesinin başpiskoposluk meselesine karıșmayacaklarına dair teminat almıștır. İngiliz idaresi yetkililerinin kanaatine göre Kitium Piskoposu çok hırslı, yönetimin başına dert açabilecek potansiyelde ve Yunanistan'la birleşme çalışmalarını kışkırtıcı bir karaktere sahipti. Bu yüzden Sinod Meclisi ile birlikte hareket edilip piskoposluk meselesinin bir an önce çözülmesinin sağlanması ve kamuoyunun da seçimlerin yasallı̆̆ konusunda idare tarafından rahatlatılması gerektiği vurgulanmıștır. ${ }^{36}$

Kitium Piskoposu ve başpiskopos adayı olan Kyrillos Papadopoulos ile onu destekleyen Kavanin Meclisi üyeleri başpiskoposluk seçimine dışardan müdahaleyi kesinlikle kabul etmediklerini her firsatta dile getirirken Girne Piskoposu Kyrillos Basileiou İstanbul Patriği III. İoakim'e başvuru yapmıștır. İstanbul Sinod Meclisinin kararıyla 28 Şubat 1908 tarihinde Girne Piskoposu Kyrillos'un başpiskopos olarak seçildiği telgrafla Kıbrıs'a bildirilmiştir. Kitium Piskoposu taraftarları Girne Piskoposunun İstanbul Fener Rum Patrikhanesi tarafından başpiskoposluğa tayin edilmesine büyük tepki göstermişlerdir. 4 Mart 1908 tarihinde Girne Piskoposunun ayin için kiliseye gittiği

32 George Hill, Kıbrıs Tarihi, Osmanlı ve Íngiliz İdaresi Dönemi (1571-1948), çev. Nazım Can Serbest (İstanbul: Türkiye İş Bankası Kültür Yayınları, 2016), 494.

3 Hill, Kıbrıs Tarihi, 494.

34 Storrs - O'Brien, The Handbook of Cyprus, 46.

35 Hill, Kıbris Tarihi, 504.

36 NA, CO, 67/125 No. 768. 
sırada Kitium Piskoposu taraftarları tarafından engellenmeye çalışılmış ve iki grubun arasında çıkan çatışmayı önlemek amacıyla kilise polis tarafından kapatılmıştır. ${ }^{37}$ Başpiskoposluk meselesinin yıllar içerisinde içinden çıkılmaz bir hal alması sebebiyle Kavanin Meclisi bir kanun taslağı hazırlamıștır. 8 Nisan 1908 tarihinde mecliste başpiskoposluk görüşmeleri yapılırken yasanın kilisenin iç işlerine karışmak olacağını düşünen Girne Piskoposu taraftarı dört yüz - beş yüz kişi Kavanin Meclisi önünde toplanmış ve başpiskoposluk binasının anahtarını istemiştir. Kitium Piskoposu taraftarlarının da Meclis önüne gelmesiyle iki grup arasında taşlı sopalı arbede yaşanmış ve gruplar polis tarafından dağıtılmıştır.

İngiliz yönetimi 25 Mayıs 1908 tarihli Resmi Gazete'nin ek sayısında başpiskopos seçimine dair kanunun kabul edildiğini ve Sömürgeler Bakanı tarafından onaylandığını ilan etmiştir. ${ }^{38}$ Bir an önce başpiskopos seçimi yapılması için bir takım maddeler ve şartlar getiren yasa, İstanbul Patrikliği tarafından Sinod Meclisi'nin kararını çiğnemek anlamına geldiğinden büyük bir hakaret sayılmıștır. Bu sebeple İstanbul Patrikliği bașpiskopos seçilen Girne Piskoposunun ada yönetimi tarafından onaylanması gerektiğini İngiliz Büyükelçisine bildirmiş ancak sonuç alamamıştır.

Kanunun resmi gazetede yayınlanmasının ardından ada yönetimi başpiskoposluk için seçim hazırlıkları yapmaya başlamış, köylere seçim ilanları göndermiştir. Ancak köylerin birçoğu zaten İstanbul Patrikliği tarafından seçilmiş bir başpiskoposları olduğu için ilanları kabul etmemiştir. Girne Piskoposu taraftarları İngiliz yönetimini, başpiskoposluk meselesine haksız yere müdahale ettiği için protesto etmiştir. Bu arada hakemliklerine başvurulan Kudüs ve İskenderiye Patriklikleri, Girne Piskoposunun seçiminin kilise kanunlarına aykırı olduğu yönünde açılama yapmıştır. ${ }^{39}$

Uzun mücadeleler sonucu tam bir çlkmaza giren başpiskoposluk meselesi Kilise krizine dönüşmüştür. İstanbul Patrikliğinin muhalefetten vazgeçip kanuna göre yapılan işlemleri kabul etmesi ile Girne Piskoposunun istifası kabul edilmiş ve 21 Nisan 1909 tarihinde Kitium Piskoposu Kyrillos Papadopoulos oy birliği ile başpiskopos olarak seçilmiştir. Koyu bir Enosisçi olan II. Kyrillos 1916 yılında ölümüne kadar başpiskoposluk makamını doldurmuştur. Seçim sonucu Yüksek Komiser tarafından da resmi olarak onaylanmıştır. ${ }^{40}$ Boşalan Kitium Piskoposluğu ile Baf Piskoposluğuna başpiskopos başkanlığında yapılan seçimle 1910 yılı Nisan ayında yeni piskopos ataması yapılmıştır. ${ }^{41}$

Bu on yıllık süreç içerisinde Kıbrıs Rum Ortodoks Kilisesi, yönetimini kilise hukuku ve yaygın uygulamalar temelinde düzenleyen bir iç yönetmelik sahibi olmuştur. $\mathrm{Bu}$

37 Osmanlı Arşivi BOA, Dahiliye Nezâreti Mektubî Kalemi [DH.MKT], No. 1255, Gömlek No. 21; KKTC Millî Arşiv ve Araştırma Dairesi MAA, Fetva Eminliği Belgeleri [FE], Kutu. 3, Dosya. 21, Gömlek. 19, Belge. 1; National Archive NA, Colonial Office [CO], 69/22.

38 The Cyprus Gazette, "Extraordinary" (25 May1s 1908), 6511 No. 919.

39 Hill, A History of Cyprus, 4/602.

40 Hill, A History of Cyprus, 4/603.

41 Hill, A History of Cyprus, 4/604. 
İngiliz İdaresi Döneminde Kıbrıs'ta İki Kilise Krizi

yönetmelik geçen on yıl içerisinde kiliseyi kasıp kavuran çatışmalara mahal vermeyecek şekilde düzenlenmiştir. ${ }^{42}$

Başpiskopos II. Kyrillos 1916 yılında ölmüş ve yerine eski rakibi Kyrillos Basileiou 24 Kasım'da III. Kyrillos unvanı ile başpiskopos olmuştur. Yüksek Komiser Sir J.E. Clauson tarafından da bu durum resmi olarak onaylanmıştır. Bu seçim bağımsız Kıbrıs Kilisesi'ni 1900'den 1910'a kadar ikiye ayıran gruplar arasındaki birliği kesin olarak tasdik etmiştir. ${ }^{43}$

1910 yılından beri Girne Piskoposluğu yapan Kyrillos Basileiou, Mart 1908 ile Nisan 1909 tarihleri arasında İstanbul Patrikliği ve Sinod Meclisi tarafından bașpiskopos olarak tanınmasına rağmen ada yönetimi tarafından kabul edilmemiştir. Kyrillos'tan boşalan Girne Piskoposluğuna ise Mart 1917'de yeğeni Makarios Myriantheus geçmiștir.

\subsection{Kilise Krizi 1933-1947}

1931 yılında Kıbrıs'ta Rumlar İngiliz idaresine karşı ayaklanmış, zamanla toplu gösteriler ve şiddet hareketleri ile olaylar büyümüştür. Başlangıçta İngiliz idaresi tarafından geçirilen gümrük ve bütçe yasası sebebiyle çıkan ${ }^{44}$ isyan, kilise ve Rum milliyetçilerinin kışkırtmaları ile Enosis propagandasına dönüşmüştür. İngiliz idaresi hükümet binasını ateşe verecek kadar ileri giden isyanları ancak takviye askeri birlikler yardımıyla bastırabilmiştir. İsyanın elebaşı olarak kabul edilen kişiler ise adadan ömür boyu sürgün edilmiştir. Adada yaşanan 1931 isyanında sürgün edilenler arasında Ortodoks din adamları Kition Metropoliti Nikodemos Mylonas ve Girne Metropoliti Makarios Myriantheus da vardır. Kition metropoliti Nikodemos Mylonas 13 Eylül 1937 tarihinde Kudüs'te sürgünde iken hayatını kaybetmiştir. ${ }^{45}$

III. Kyrillos'un 1933 yılı Kasım ayında ölmesi ile yerine başpiskopos vekili olarak görev yapan Baf Metropoliti Leontios Leontiou, diğer iki metropolitin adada olmaması sebebiyle uzun süre seçim yapamamıștır. Leontios bir önceki Bașpiskopos III. Kyrillos'un aksine koyu bir Enosis taraftarıydı. Leontios Enosis'i gerçekleștirmek amacıyla adadaki sağ ve sol siyasi unsurları bir araya getirmeye, arabuluculuk yapmaya çalışmıştır. $\mathrm{Bu}$ dönemden itibaren Leontios'un çalışmaları sonucunda başpiskoposluk makamı her zaman siyasi belirleyicilerden biri olmuştur. $\mathrm{Bu}$ dönemde Leontios'un sürgündeki metropolitlerin adaya geri dönmelerine yönelik İngiliz idaresine yaptığı müracaatlar da sonuçsuz kalmıştır. İstanbul Patriği II. Fotios, Atina Başpiskoposu ve İskenderiye Patriği başpiskoposluk seçiminin yapılması için metropolitlerin fiilen adada bulunmaları gerekmediğini, oylarını uzaktan kullanmalarının da mümkün olduğunu bildirmişlerdir. Buna rağmen Leontios sürgündeki piskoposlar adaya dönmeden seçimin yapılmasının yasal olmadığında ısrar ederek uzun yıllar bu başpiskoposluk görevini vekâleten yürütmüştür. Leontios, Enosis konusundaki kışkırtıcı söylemleri ve Enosis faaliyetlerine ısrarla devam etmesi sebebiyle İngiliz idaresi tarafından para cezasına çarptırılmıştır.

42 Theodoros Papadopoulos, Social and Historical Data on Population (1570-1881) (Lefkoşa: Cyprus Research Centre, 1965), 127; Hill, Klbris Tarihi, 516.

43 Hill, Kıbrıs Tarihi, 698.

44 Turgay Bülent Göktürk, "Rum Ortodoks Kilisesi’nin Kıbrıs’ta Karar Alma Sürecine Etkisi”, Çağdaş Türkiye Tarihi Araştırmaları Dergisi 15/30 (01 Haziran 2015), 315.

45 Hill, Kıbris Tarihi, 517.

https://dergipark.org.tr/tr/pub/atebe 
1938-1940 yılları arasında ise Baf Belediye sınırları dışına çıkması yasaklanarak göz hapsinde tutulmuştur. ${ }^{46}$

Bu dönemde aynı zamanda II. Dünya Savaşı'nın devam etmesi sebebiyle İngiliz idaresi zor zamanlar geçirmekteydi. Kıbrıslı Rumlar bu süreçte Leontios'un teşvikiyle İngiliz cephelerinde gönüllü askerlik yapmıştır. Siyasi bir taktik olarak adanın Yunanistan'a bağlanması yolunda Leontios'un bu hamlesi başarılı olmuş, savaş sonrası süreçte, 1947 yılının başında adaya vali olarak atanan Lord Winster İngiliz Hükûmeti tarafından isyan sürecinde çıkarılan yasaları yumuşatma talimatı almıştır. Lord Winster bu talimata binaen 1931 isyanı sonrası çıkarılan Kilise yasalarını feshetmiş, sürgüne gönderilenlerin de adaya dönmelerine izin vermiştir.

Uzun ve sancılı bir süreç sonunda 1946 yılında adada kilise hakkında çıkarılan yasaların feshedilmesi sonucunda sürgünde olanlar geri dönmüş ve her defasında aday olmayacağını açıklayan başpiskopos vekili ve Baf Piskoposu Leontios 29 Haziran 1947 tarihinde başpiskopos seçilmiştir. Ekümenik Patriğin temsilcisi olarak adada bulunan Terkos Metropoliti de kendisini seçmenlerin kararını kabul etmeye ikna etmiştir. Böylece başpiskoposluk sorunu bir kez daha çözüme kavuşmuştur. Bu seçim başpiskoposluk makamında uzun süren bir boşluğa son vermesi dışında fanatik bir Enosis yanlısının Kıbrıs Rum Ortodoks Kilisesi'nin yeni lideri olması bakımından da önemlidir. ${ }^{47}$

Leontios, başpiskopos seçildikten iki ay sonra hastalanarak ölmüştür. Leontios'un ardından 1931 isyanındaki kışkırtmaları nedeniyle sürgüne gönderilen, adaya döndükten sonra da Girne Metropoliti seçilen, II. Kyrillos'un yeğeni Makarios Myriantheus, Ekim 1947'de yapılan seçimle başpiskopos olmuş ve II. Makarios unvanını almıştır. II. Makarios 1950 tarihinde ölmüş, yerine 1948 yılından beri Kition piskoposu olan ve kurulacak olan Kıbrıs Cumhuriyeti'nin de ilk Cumhurbaşkanı olacak olan III. Makarios geçmiştir. ${ }^{48}$

\section{Sonuç}

Kıbrıs Adası'nda İngiliz yönetiminin egemen olduğu 1878 yılından Birinci Dünya Savaşı'na kadar olan dönemde Ortodoks Rumların Enosis hayalleri, Türk toplumuna karşı giriştikleri sindirme hareketleri ile Yunanistan ve İngiltere'den aldıkları destek ve mücadele ile geçtiğini söylemek mümkündür. ${ }^{49}$ Birinci Dünya Savașı'ndan sonra İngiltere'nin Kıbrıs Adası'nı ilhakı ile Enosis konusunda Rumlar artık Osmanlı toprağı olmayan Kıbrıs'ın Yunanistan'a bağlanması için Helen ideali için çalışmış, İngilizlerin bu konudaki olumsuz geri dönüşleri sebebiyle hırçınlaşmıştır. 1960 yılında Kıbrıs Cumhuriyeti'nin kurulması da Kıbrıs Rum Ortodoks Kilisesi ve Rumları Enosis düşüncesinden vazgeçirmemiştir. Kendi aralarında çekişmekten de geri durmayan Ortodoks Rumlar, kilise idaresindeki milliyetçilik devinimini III. Makarios' un başpiskopos olması ile tamamlamıştır. 1900-1910 ve 1933-1947 yılları arasında cereyan eden kilise krizleri, ada içerisinde ciddi tartışmalara yol açarken, ada dışında da Kıbrıs Rum Ortodoks Kilisesi'nin bağımsızlık ilkesini sarsacak gelişmelere şahit olmuştur.

46 Göktürk, “Rum Ortodoks Kilisesi’nin Kıbrıs’ta Karar Alma Sürecine Etkisi”, 320.

47 Hill, Kıbrıs Tarihi, 519; Yıldırım, Kıbrıs Rum Ortodoks Kilisesi, 76; Kızılyürek, Milliyetçilik Kıskacında Kıbrls, 80 .

48 Hill, Klbrıs Tarihi, 519.

49 Yıldırım, Kibris Rum Ortodoks Kilisesi, 77. 
İngiliz İdaresi Döneminde Kıbrıs'ta İki Kilise Krizi

Enosis düşüncesi çerçevesinde gelişen başpiskoposluk seçimleri bugün dahi hem siyasi seçimlerde hem de kilisenin müdahil olduğu tartışmalarda etken olmaya devam etmektedir. Enosis, kilise içinde ve dışında en etkili propaganda aracı olmaya devam etmektedir. Bu iki kriz bunu en bariz şekliyle göstermektedir.

\section{Kaynakça}

Alasya, Halil Fikret vd. "İngiliz İdaresinde Tatbik Edilen Politika". Kıbrıs ve Türkler. Ankara: Türk Kültürünü Araştırma Enstitüsü, 1964.

Alasya, Halil Fikret. Kıbrıs ve Rum-Yunan Emelleri. Lefkoşa: KKTC Milli Eğitim ve Kültür Bakanlığı, 1992.

BOA, Osmanlı Arşivi. Dahiliye Nezâreti Mektubî Kalemi [DH.MKT]. No. 1255, Gömlek No. 21.

BOA, Osmanlı Arşivi. Hariciye Nezâreti Hariciye Tercüme Odası [HR.TO]. No. 530, Gömlek No. 10.

Bozkurt, Bekir. İngiltere'nin Kıbrıs Adasını Ilhak Süreci. Ankara: Ankara Üniversitesi, Sosyal Bilimler Enstitüsü, Yüksek Lisans Tezi, 2005.

Cavendish, Anne (ed.). Cyprus 1878: The Journal of Sir Garnet Wolseley. Nicosia: Cultural Centre of the Cyprus Popular Bank, 1991.

Çelik, Cemil. Íngiliz Yönetiminde Kıbrıs'ın İdari ve Sosyal Durumu (1878-1914). Antalya: Akdeniz Üniversitesi, Sosyal Bilimler Enstitüsü, Doktora Tezi, 2012.

Demirci, Kürşat. "Ortodoksluk". Türkiye Diyanet Vakfı İslâm Ansiklopedisi. 33/374-380. Ankara: TDV Yayınları, 2007.

Duckworth, Henry Thomas Forbes. The Church of Cyprus. London: Society for Promoting Christian Knowledge, 1900.

Englezakis, Benedict. Studies on the History of the Church of Cyprus, 4th-20th Centuries. Great Britain: Variorum, 1995.

Gazioğlu, Ahmet C. İngiliz Yönetiminde Kıbrıs II, 1878-1952: Enosis Çemberinde Türkler. İstanbul: Kıbrıs Araștırma ve Yayın Merkezi (CYREP), 1996.

Göktürk, Turgay Bülent. "Rum Ortodoks Kilisesi'nin Kıbrıs'ta Karar Alma Sürecine Etkisi”. Çăgdaş Türkiye Tarihi Araştırmaları Dergisi 15/30 (01 Haziran 2015), 295-345.

Göktürk, Turgay Bülent. “Rumlar'ın Kıbrıs'taki Enosis İsteklerinin Şiddete Dönüşmesi: 1931 İsyanı”. Çağdaş Türkiye Tarihi Araștırmaları Dergisi 7/16-17 (2008), 335-363.

Gürel, Şükrü S. Kıbrıs Tarihi (1878-1960): Kolonyalizm, Ulusçuluk ve Uluslararası Politika. Ankara: Kaynak Yayınları, 1984.

Hill, George. Kıbrıs Tarihi, Osmanlı ve İngiliz İdaresi Dönemi (1571-1948). çev. Nazım Can Serbest. İstanbul: Türkiye İș Bankası Kültür Yayınları, 2016.

Hill, Sir George Francis. A History of Cyprus. 4 Cilt. Cambridge: Cambridge University Press, 1952.

Holland, Robert F. - Markides, Diana Weston. Britain and the Hellenes: Struggles for Mastery in the Eastern Mediterranean 1850-1960. Oxford: Oxford University Press, 2006.

https://dergipark.org.tr/tr/pub/atebe 
Kızılyürek, Niyazi. Milliyetçilik Kıskacında Kıbrıs. İstanbul: İletişim Yayınları, 2002.

MAA, KKTC Millî Arşiv ve Araştırma Dairesi. Fetva Eminliği Belgeleri [FE]. Kutu. 3, Dosya. 21, Gömlek. 19, Belge. 1.

Mallock, W. H. (William Hurrell). In an Enchanted Island or A Winter's Retreat in Cyprus. London: R. Bentley \& Son, Third Edition., 1892. http://archive.org/details/inenchantedisla00mall

NA, National Archive. Colonial Office [CO]. 69/14.

NA, National Archive. Colonial Office [CO]. 67/125.

NA, National Archive. Colonial Office [CO]. 69/22.

Papadopoulos, Theodoros. Social and Historical Data on Population (1570-1881). Lefkoşa: Cyprus Research Centre, 1965.

Savrun, Ergenekon. "1571 Türk Yönetiminden, 1878-1925 İngiliz Taç Kolonisi’ ne; Kıbrıs Üzerinde Enosis Faaliyetleri ve İngiliz Stratejisi”. Uluslararası Beșeri Bilimler ve Eğitim Dergisi 3/1 (01 Nisan 2017), 1-20.

Scott-Stevenson, Esmé. Our Home in Cyprus. Chapman and Hall, 1880.

Storrs, Sir Ronald - O’Brien, Bryan Justin. The Handbook of Cyprus. London: Christophers, 1930.

Şengil, Mustafa. Mavi Vatanın Kudüsü (Kıbrıs'ta Din ve Siyaset). İstanbul: Hikmetevi Yayınları, 2021.

Yıldırım, Münir. Kıbrıs Rum Ortodoks Kilisesi: İlk Dönem Bir Hristiyan Kilisesi Olarak. Ankara: Aziz Andaç, 2008.

The Cyprus Gazette. "Extraordinary" (25 Mayıs 1908), 6511.

The Cyprus Gazette (22 Şubat 1907), 6103-6106.

The Cyprus Gazette (20 Mart 1908), 6405-6407. 